\title{
自治体におけるビル風に関する環境影響評価の実態調査 \\ Survey on Impact Assessment of Pedestrian Wind Environment in Municipalities in Japan
}

\author{
作田美知子 ${ }^{* 1}$
}

Michiko SAKUTA
白澤多一 *2

富永禎秀*3

Taichi SHIRASAWA Yoshihide TOMINAGA
1.はじめに

「環境影響評価」とは，事業の実施が環境に及ぼす影 響について環境の構成要素に係る項目ごとに調査・予 測・評価を行い，その事業の環境保全の措置を検討し， 環境影響を総合的に評価することをいう。平成 5 年に制 定された「環境基本法」に基づいて, 自治体毎に条例等 が設けられ，環境影響評価が行われている。この環境影 響評価の項目に, 自治体によっては風環境（ビル風, 風 害，局地風等とも表記される）が含まれる。その場合, 各自治体の環境影響評価制度および技術指針等に基づい て，事業の実施が風環境に及ぼす影響が予測・評価され ることになる。

各自治体の環境影響評価制度における風環境 (風害) の扱いについては，文献 1,2 や資料 3 において概説され ているが，最新の現状や全体像が十分明らかになってい るとは言えない。また同制度を運用する立場である行政 担当者の認識や問題意識を知ることは，風環境評価に関 する現状の課題を整理する上で重要であると考えられる。

このような背景から, 日本風工学会・都市の風影響評 価研究会の活動の一環として, 標記の実態調査を実施す ることとした。調査は大きく 2 つからる。1つ目は，イ ンターネット上の情報に基づく, 各自治体の風環境に係
わる環境影響評価制度の実態調査であり，2つ目は，各自 治体の環境影響評価制度担当者を対象としたアンケート 調査である。本調査で整理した資料全体は膨大であり, 限られた紙面で全てを整理，公開することは困難である。 本稿では, 調査の概要と結果の一部を紹介し, さらに詳 細な報告は, 今後学会 HP 等において行う予定である。 なお, インターネット調査においては, 細心の注意を払 ってはいるが，見落としや判断の違いによる漏れ等が無 いとは言えない点をあらかじめお断りしておく。

\section{2. 調査の方法}

2. 1 インターネットによる評価制度の現状調査

(1) 調查対象

調査対象とする地方自治体は, 環境省の地方公共団体 のアセスメント制度の $\mathrm{HP}^{4}$ に平成 28 年 3 月 31 日現在の 「都道府県・市町村における環境影響評条例評価制定・ 施行状況等」に掲載されている 47 都道府県, 17 政令市, 8 市の自治体に東京 23 区を加えた計 95 自治体である。

(2) 調査方法

基本的な調查の流れは，文献 1 の同様の調查での方法 を参考に，以下の通り実施した。

(1) インターネットにより各地方自治体の環境影響評価

\footnotetext{
* 1 三井住友建設株式会社 技術本部 技術研究所 Technical Research Institute, Sumitomo Mitsui Construction Co., Ltd.

* 2 大妻女子大学 准教授 Associate Professor, Otsuma Women's University

* 3 新潟工科大学 教授 Professor, Niigata Institute of Technology
} 
条例等を検索し，閲覧する。

(2) 風環境に関連するキーワードとして,「風」「風害」等 を随時検索し，記載の有無を調べる。

(3) 条例等への記載の有無に係わらず, 同条例の技術指針 や技術指針マニュアル等も検索した。大気環境等，風 が関係しているものの, いわゆるビル風を対象として いないものは，内容を確認した上で除外する。

(4) 風環境に関連する項目について, 規定されている建物 の規模, 調查方法, 予測方法, 評価方法等を調查する。

(3) 調査時期

2017 年 12 月下旬から 2018 年 1 月中旬に実施された。 インターネット上の情報は，全てこの期間にアクセス可 能であったものに基づいている。

2. 2 担当者へのアンケート調査

(1) 調査対象

インターネットによる調查と同じ，47 都道府県，17 政 令市，8市，23 区の 95 自治体に送付した。

(2) 調查方法

切手付き返信用封筒を同封し，各自治体の「環境影響 評価制度ご担当者様」宛として送付した。アンケートの 内容を表 1 に示す。

(3) 調查時期

2017 年 12 月 22 日に発送し, 2018 年 1 月 22 日を返送 の締め切りとした。

3.インターネットによる制度調査の結果

3. 1 全体的な傾向

調査した全自治体のうち，環境影響評価制度において 風環境に係わる項目がある自治体は, 表 2 に示寸 32 自治 体であった。殆どの自治体において，環境影響評価条例 では，全体的な評価制度の枠組みが述べられており，直 接, 風環境といった具体的な項目には触れられていない 場合も多い。多くの自治体では，同条例の技術指針や技 術指針マニュアル等によって, 具体的な調查・予測・評 価について規定されている。なお,「中高層建築物の建築 に係る紛争の予防と調整に関する条例」を制定し，近隣 関係住民と建築主との間の紛争の一つとして風害を扱つ ている自治体も多い。

文献 1 の調查では,「環境影響評価条例の中で風害等が 明示されており，かつ対象事業として高層建築物を指定 している地方自治体は20件であった」との記載があるが, 表 2 に示した一覧は, 対象事業の要件を限定していない ため, 高層建築物や大規模建築物の新設を対象事業とし て指定していないものも含まれる点に注意されたい。な
表 1 アンケート調査の内容

問1 貴自治体には, 風害 (ビル風) に関する環境影響評価（ア セスメント)の制度がありますか。

1.ない $\rightarrow$ 問 7 にお進みください。

2.ある $\rightarrow$ 問 2 にお進みください。

問 2 過去 3 年間で, 貴自治体において, 風害 (ビル風) に関 する環境影響評価（アセスメント）の対象となった事業はあり ますか?
1.ない $\rightarrow$ 問 7 にお進みください。
2.ある $\rightarrow$ 問 3 にお進みください。

問 3、環境影響評価（アセスメント）の対象となった事業があ る場合，そのおおよその件数をご回答ください。
2014 年度 :
2015 年度 :
2016 年度：
件
件
件

問 4.上記の環境影響評価 (アセスメント) において, 風害 (ビ ル風）の予測に用いられた手法のおおよその件数をご回答くだ さい。

2014 年度：

風洞䒠験: 件
数值流体シミュレーション: 件
その他: 件

2015 年度：

風洞実験：件
数值流体シミュレーション: 件

その他： 件

2016 年度：

風洞実験: 件

数值流体シミュレーション：件

その他：件

問5。風害（ビル風）の環境影響評価（アセスメント）に関し て，事業者やコンサルタントとの対応で期待していること，あ るいは困っていることはありますでしょうか?

1.ない

2.ある

2. と回答した方は，具体的に差支えない範囲でお書きくだ さい。

問6。風害（ビル風）の環境影響評価（アセスメント）に関し て，住民との対応で改善したい課題はありますでしょうか?

1.ない

2.ある

2. と回答した方は，具体的にどのような内容か差し支えな い範囲でお書きください。

問 7. 風害（ビル風）に関する住民からの苦情や相談を受けた 事例がありますか?

1. どちらもない

2. 事例がある

2 と回答した方は，差し支えなければ，どのような苦情や相 談を受けたのか, お書きください。

問 8 , 日本風工学会への要望がありましたら, お書きくださ い。

ご協力ありがとうございました。

お, 高層建築物が対象事業となる場合の規模要件として は, 高さ 100 メートル以上，延べ床面積は 10 万 $\mathrm{m}^{2}$ ない 
し 5 万 $\mathrm{m}^{2}$ 以上と規定している自治体が多い。

3. 2 風環境に係わる環境影響評価制度の例

(1) 東京都 ${ }^{5)}$

東京都では, 昭和 56 年 10 月から「東京都環境影響評 価条例」の基づいた環境影響評価制度が実施されている。 現在まで何回かの改定を経て, 環境影響評価の項目は風 害を含む 16 項目となっており, 事業の内容により検討す べき項目が選定される。環境影響評価制度の適用を受け る事業は道路の新設等 26 種類あり, この中に ‘高層建築 物の新築’が含まれ, 対象事業の要件が高さ $100 \mathrm{~m}$ を超 えかつ延べ面積 10 万 $\mathrm{m}^{2}$ を超えるもの, 特定の地域につ いては, 高さ $180 \mathrm{~m}$ を超えかつ延べ面積 15 万 $\mathrm{m}^{2}$ を超える ものと規定されている。

選定された評価項目に対して，その項目の環境影響評 価に必要な調査, 予測方法, 評価方法等は「東京都環境 影響評価技術指針（付解説）」》れ記述されている。技術 指針の「第 12 風環境」の要約を表 3 中に示す。風害の予 測方法は, 風洞実験による方法, 数值流体シミュレーシ ヨン（以下, CFD という) による方法, その他適切な方 法から選択, または組合せて行うこととされている。評価の指 標は, 村上らの評価指標 ${ }^{8}$ および風工学研究所の評価指標 ${ }^{1)}$ が記載され，「強風の発生頻度を考慮した風環境評価尺 度を用いることとし，ビューフォートの風力階級等風速 の発生頻度が考慮されていない指標を用いてはならな いとされている。

なお, 環境影響評価の対象の項には, 上述の要件を超 えなくとも，「高さが $60 \mathrm{~m} を$ 超える建築物」及び「周辺の 建築物の平均的高さより5 6倍以上高い建築物」等が建 設され，「事業計画地の周辺の土地利用状況及び建物状況 により風環境に影響を及ぼすことが予想される場合」に 該当する場合は，「風環境を予測・評価項目として選定す ることを検討する。」されている。しかしながらこのよ うな大規模な建築物は, 通常は, 都市整備局が管轄する 総合設計制度の規定に従うことになる。「東京都総合設計 許可要綱実施細目」 $\left.{ }^{9}\right)$ では, 高さ60 m以上（商業地域以外 の用途地域では高さ $45 \mathrm{~m}$ 以上）の建築物に対して風害の 調查が義務付けられている。特に，100m以上（商業地域 以外の用途地域では60m以上）の建築物は「風洞実験を 行うとともに, 原則として, 風向・風速計を設置し, 建 設前・後の観測を行うこと」との記載がある。

(2) 東京都港区

東京 23 区の中で唯一独自に「港区環境影響調査実施要 綱」を定めている。さらに, 平成 25 年に「港区ビル風対 策要綱」を制定し，風環境影響の予測及び対策について
表 2 風環境に係わる評価項目がある環境影響評価条例

\begin{tabular}{|c|c|}
\hline 条例 & 評価項目 \\
\hline 札幌市環境影響評価条例 & 風害 \\
\hline 仙台市環境影響評価条例 & 風害 \\
\hline 青森県環境影響評価条例 & 風害 \\
\hline 埼玉県環境影響評価条例 & 風害 (局所的な風の発生状況) \\
\hline さいたま市環境影響評価条例 & 風害 (局所的な風の発生状況) \\
\hline 千葉県環境影響評価条例 & 風害, 光害及び日照阻害 \\
\hline 東京都環境影響評価条例 & 風環境 \\
\hline 港区環境影響調査実施要綱 & ビル風 \\
\hline 神奈川県環境影響評価条例 & $\begin{array}{l}\text { 気象 (変更される土地の形状 } \\
\text { 又は設置される工作物によっ } \\
\text { て変化する風向及び風速) }\end{array}$ \\
\hline 横浜市環境影響評価条例 & 風害 \\
\hline $\begin{array}{l}\text { 川崎市環境影響評価に関寸る条 } \\
\text { 例 }\end{array}$ & 構造物の影響（風害） \\
\hline 相模原市環境影響評価条例 & $\begin{array}{l}\text { 大気環境（大気質，騷音・超 } \\
\text { 低周波音，振動，悪臭，風環 } \\
\text { 境） }\end{array}$ \\
\hline 富山県環境影響評価条例 & $\begin{array}{l}\text { その他（気象，風害，低周波 } \\
\text { 空気振動等) }\end{array}$ \\
\hline 長野県環境影響評価条例 & $\begin{array}{l}\text { その他の環境要素（日照阻害, } \\
\text { 電波障害, 風害, 光害) }\end{array}$ \\
\hline 静岡県環境影響評価条例 & 局地風 \\
\hline 静岡市環境影響評価条例 & 局地風 \\
\hline 名古屋市環境影響評価条例 & 風害 \\
\hline $\begin{array}{l}\text { 京都市環境影響評価等に関する } \\
\text { 条例 }\end{array}$ & 風害 \\
\hline 大阪府環境影響評価条例 & $\begin{array}{l}\text { 気象 (風向・風速, 気温, 局 } \\
\text { 地風系 (海陸風, 山谷, ビ } \\
\text { ル風等の局地的な風系を含 } \\
\text { む。)) }\end{array}$ \\
\hline 大阪市環境影響評価条例 & 気象（風害を含む） \\
\hline 堺市環境影響評価条例 & 風害 \\
\hline $\begin{array}{l}\text { 豊中市環境の保全等の推進に関 } \\
\text { する条例 }\end{array}$ & $\begin{array}{l}\text { 気象 (風向, 風速, 局地風（ビ } \\
\text { ル風等）, 気温, 湿度等) }\end{array}$ \\
\hline $\begin{array}{l}\text { 吹田市環境まちづくり影響評価 } \\
\text { 条例 }\end{array}$ & 風害 \\
\hline 枚方市環境影響評価条例 & 風害 \\
\hline $\begin{array}{l}\text { 神戸市環境影響評価等に関する } \\
\text { 条例 }\end{array}$ & 風害 \\
\hline $\begin{array}{l}\text { 尼崎市環境影響評価等に関する } \\
\text { 条例 }\end{array}$ & 風害 \\
\hline 和歌山県環境影響評価条例 & $\begin{array}{l}\text { 気象 (風向及び風速(風害を含 } \\
\text { む。)) }\end{array}$ \\
\hline 広島市環境影響評価条例 & $\begin{array}{l}\text { その他の環境（日照阻害，電 } \\
\text { 波障害，風害） }\end{array}$ \\
\hline 山口県環境影響評価条例 & $\begin{array}{l}\text { その他の大気環境（風害，塩 } \\
\text { 害等) }\end{array}$ \\
\hline 北九州市環境影響評価条例 & $\begin{array}{l}\text { その他環境要素（日照, 風害, } \\
\text { 低周波音, その他) }\end{array}$ \\
\hline 福岡市環境影響評価条例 & $\begin{array}{l}\text { その他の環境（日照阻害，風 } \\
\text { 況） }\end{array}$ \\
\hline 沖縄県環境影響評価条例 & 風害 \\
\hline
\end{tabular}

「ビル風対策に係る手引」 ${ }^{10)}$ を定めている。この中では, 防風植栽について竣工時の設置確認だけでなく, 生育状 況の確認として竣工後最長 3 年までの手続きとされてい る。対象となる事業は延べ床面積 5 万 $\mathrm{m}^{2}$ 以上の開発事業 と規定されている。 
表 3 環境影響評価制度技術指針における風環境に係わる記載の例（要約）

\begin{tabular}{|c|c|c|}
\hline & 東京都 & 川崎市 \\
\hline $\begin{array}{l}\text { 調 } \\
\text { 查 } \\
\text { 方 } \\
\text { 法 }\end{array}$ & $\begin{array}{l}\text { 地域の風の状況 } \\
\text { ・上空風の状況 } \\
\text { 既存資料の整理·解析又は現地調查の方法による. 現地調 } \\
\text { 查の場合, 観測方法は「地上気象観測指針」に準拠する. } \\
\text { •地表付近の風の状況 } \\
\text { 既存資料の整理·解析又は現地観測の方法による. 現地観 } \\
\text { 測の場合, 上空風の調査に準しる. 上空風の調査結果を基に } \\
\text { 地表付近の風環境を把握する場合は, 風洞実験又は流体数值 } \\
\text { シミュレーシヨンの方法による. } \\
\text { •強風の状況 } \\
\text { 既存資料の整理·解析又は現地調査の方法による. } \\
\text { 他, 配慮すへさ施設·建築物・地形等の状況 } \\
\text { 既存資料の整理·解析又は現地調査の方法による. }\end{array}$ & 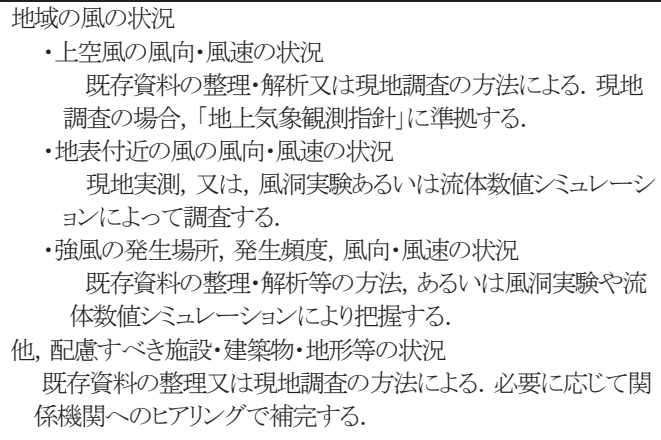 \\
\hline $\begin{array}{l}\text { 予 } \\
\text { 測 } \\
\text { 項 } \\
\text { 目 }\end{array}$ & $\begin{array}{l}\text { 次から必要なものを選択する. } \\
\text { •平均風向, 平均風, 最大風速等の突風の状況並びにそれらの変 } \\
\text { 化する地域の範囲及び変化の程度 } \\
\text { ·年間におけする強風の出現頻度 }\end{array}$ & 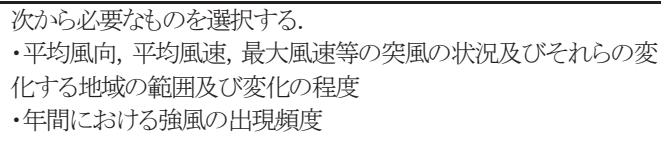 \\
\hline $\begin{array}{l}\text { 予 } \\
\text { 測 } \\
\text { 方 } \\
\text { 法 }\end{array}$ & $\begin{array}{l}\text { 次のうちから適切なものを選択し, 又は組み合わせて行う. } \\
\text { ·風洞実験による方法 } \\
\text { ·流体数値シミュレーションによる方法 } \\
\text { •その他適切な方法 }\end{array}$ & $\begin{array}{l}\text { 次のうちから適切なものを選択し, 又は組み合わせて行う. } \\
\text { •風洞実験による方法 } \\
\text { •流体数值シミュレーションによる方法 }\end{array}$ \\
\hline $\begin{array}{l}\text { 評 } \\
\text { 価 } \\
\text { 方 } \\
\text { 法 }\end{array}$ & $\begin{array}{l}\text { 現況調査及び予測の結果に基づき, 地域の特性, 環境保全のため } \\
\text { の措置及び評価の指標を勘案して, 事業の実施に伴亏風環境の変化 } \\
\text { の程度について明らかにする. } \\
\text { (評価の指標) } \\
\text { ·村上周三氏らの提案による風環境評価基淮 } \\
\quad \text { (居住者の日誌による風環境調査と評価尺度に関する研究 日本 } \\
\text { 建築学会論文報告集第325号) } \\
\text { ·風工学研究所の提案による風環境評価基準 } \\
\text { (市街地の風の性状 第9回風工学シンポジウム論文) } \\
\text { •その他の客観性を有する指標 }\end{array}$ & $\begin{array}{l}\text { 現状調査及び予測の結果に基づき, 地域の特性, 環境保全のた } \\
\text { めの措置及び評価の指標を勘案して, 事業の実施に伴う風環境 } \\
\text { の変化の程度について明らかにする. } \\
\text { (環境保全目標) } \\
\text { •地域環境管理計画に定める地域別環境保全水淮 } \\
\text { •日最大瞬間風速の超過頻度に基づく環境評価尺度 } \\
\text { ·平均風速の累積頻度に基づく風環境評価尺度 } \\
\text { •その他の科学的知見(ビューフォートの風力階級表のほか, 学 } \\
\text { 会等において研究の成果として発表された知見等. ) }\end{array}$ \\
\hline $\begin{array}{l}\text { 事 } \\
\text { 後 } \\
\text { 調 } \\
\text { 查 }\end{array}$ & $\begin{array}{l}\text { 「東京都環境影響評価事後調査基淮」より } \\
\text { •調査事項は, 評価書に記載した予測事項の状況, 事後調査実施時 } \\
\text { における予測条件の状況及び環境保全のための措置の実施状況. } \\
\text { ·調査地域は, 評価書に記載した予測地域. } \\
\text { •調査は, 現地調査又は既存資料の整理·解析の方法により, 次の通 } \\
\text { り実施する。 } \\
\text { 調査時点は予測の対象時点. } \\
\text { 調査地点は, 環境影響を面的に予測したものについて現地調 } \\
\text { 查を行う場合は, 予測地域内に代表点を設置. }\end{array}$ & $\begin{array}{l}\text { ·調査項目は主に地表付近の風向及び風速の状況とする. } \\
\text { ·調査地点は, 予測点のうち, 風害の影響が大きくなると予測され } \\
\text { た地点とする. } \\
\text { ·調查時期は、予測において設定した予測時期とする. 調査期間 } \\
\text { は, 風環境評価基淮との対比ができるように1年以上とする. } \\
\text { ·調査方法は原則として, 現況調査における現地調査の方法によ } \\
\text { るが, 防風植栽等の環境保全のための措置の履行状況や効果に } \\
\text { つても把握できるように行う.また、居住者や歩行者など住民等 } \\
\text { へのアンケートによる万法も検討する. }\end{array}$ \\
\hline
\end{tabular}

\section{(3) 川崎市}

川崎市では，昭和 51 年に全国に先駆けて「川崎市環境 影響評価に関する条例」を制定し，その後の社会経済状 況の変化や平成 9 年に「環境影響評価法」が公布された ことから，平成 12 年 12 月より新たな条例に基づいた環 境影響評価制度が実施されている。制度の適用を受ける 事業は道路の新設等 15 種類あり，この中に‘高層建築物 の新設’および ‘大規模建築物の新設’が含まれる。そ れぞれの対象事業の要件は, 第一種行為では高さ $100 \mathrm{~m}$ 以 上かつ延べ面積 5 万 $\mathrm{m}^{2}$ 以上のもの，延べ面積 10 万 $\mathrm{m}^{2}$ 以 上のもの（臨港地区は除く）とされている。「川崎市環境 影響評価等技術指針 ${ }^{11)}$ の第 5 章第 18 構造物の影響 (風
害)」の要約を表 3 中に示す。

3. 3 風環境の予測, 評価方法, 事後調查について 風環境に関する評価制度をもつ 32 の自治体の多くで, 風環境の調查方法や予測方法が具体的に示されている。 予測方法は，東京都と同様，風洞実験による方法と CFD による方法に加え，類似事例からの推定する方法やその 他適切な方法等が示されている。予測方法の名称のみを 記載する自治体が多いが，東京都や川崎市等のいくつか の自治体では，予測条件が記載され，予測に用いた諸量 の数值, 予測計算の仮定を明確にすることを求める記載 がある。例えば, CFD では計算条件, 乱流モデル・方法, 解析メッシュ，境界条件等の記載が求められている。 
評価方法として，具体的な評価指標の名称の記載があ る自治体は約 $1 / 3$ であった。この数には評価指標を参考 資料に記載している自治体の数も含まれる。いずれの自 治体も評価指標を複数記載しており, 風工学研究所の評 価指標および村上らの評価指標の他，ダベンポートの方 法やビューフォートの風力階級を記載する自治体もある。 風工学研究所の評価指標や村上らの評価指標は 1980 年代 に提案され, 提案から 30 年経た現在においても大きな役 割を果たしているといえる。

事後調査については半数以上の自治体で記載がある。 事後調查方法は現地調查が主であるが, 事後調査の記載 があった自治体のうち約 $1 / 3$ の自治体では「住民等への アンケートによる方法も検討寸る」等記載されている。

\section{4. 自治体担当者へのアンケート調査結果}

アンケートの回収率は $69.5 \%$ (66 件／95 件) であった。 アンケートの内容は表 1 に示している。問 1 の風害（ビ ル風）に関する環境影響評価の制度の有無に対する回答 割合を図 1 に示す。アンケートに対する回答のあった自 治体中のおよそ $1 / 3$ の自治体が，風害（ビル風）に関す る環境影響評価の制度があると回答している。当然なが ら, 制度の有無はインターネットによる調査結果とほぼ 対応するが，食い違う自治体もわずかに見受けられた。

これは設問に対寸る解釈の相違と思われる。

問 2 は, 評価制度を有する自治体に対する質問である。 問 2 の過去 3 年における風害（ビル風）に関する環境影 響評価の対象となった事業の有無に対する回答割合を図 2 に示寸。「ある」と回答した自治体は約 3 割（8 自治体） であった。すなわち風環境に関する環境評価制度を有し ていても，実際に評価制度が適用されている割合は比較 的少ない。

問3〜問 6 は過去 3 年間に風害に関する環境影響評価の 対象となった事業があった自治体一の質問である。問 3 の過去 3 年での風害（ビル風）に関する環境影響評価の 対象となった事業の件数に対する回答から, 過去 3 年間 の対象事業数は 29 件であった。東京都が全数の約半分の 14 件であり, その他の 7 自治体はそれぞれ 1 3 件程度と 実施件数はそれほじ多くない。問 4 の環境影響評価にお いて，風害（ビル風）の予測に用いられた手法に対する 回答割合を図 3 に示寸。予測に用いられた手法の約 8 割 が風洞実験であった。東京都では寸べての対象事業で風 洞実験を用いた予測が行われていたが，その他の自治体 ではCFD も用いられている。問 5 の風害（ビル風）の環 境影響評価に関して，事業者やコンサルタントとの対応

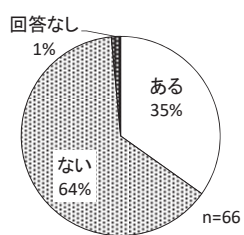

図 1 風害に関する評価 制度の有無（問 1）

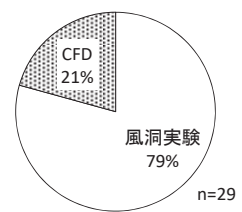

図3 風害予測で用いられ た手法の割合（問 4)

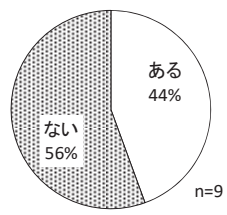

図 5 住民との対応での 課題の有無 (問 6)

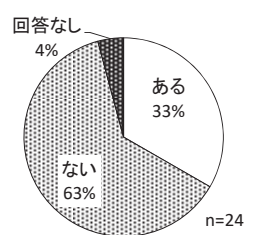

図 2 制度の対象となった 事業の有無（問 2)

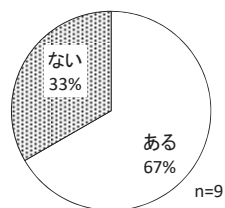

図4 事業者らとの対応 での課題の有無 (問 5)

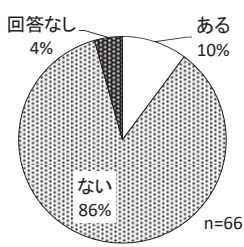

図 6 風害に関する住民か らの苦情や相談 (問 7)
表 4 アンケートにおけるコメント一例（要約)

問 5 事業者らとの対応で期待していること, 困っていること

・手続きを通じて環境影響を的確に把握し, 可能な限り周辺環境 に配慮した建築計画の検討を期待する.

・防風対策に過度の期待をせずに, 建物形状や配置での対策を行 うことを期待する.

・予測に対して事後調査の結果が悪かった場合, 責任をもって風 環境改善のための対策を行ってほしい.

・計画地周辺において, 他の高層建築物の建設が予定されている 場合, その影響を加味したケースの予測も行うことが望ましい.

・予測に用いる上空風のデータは予測が過小評価とならないよう 適切な地点を選択が必要である.

問 6 住民との対応で改善したい課題

・風環境評価指標がどのような風環境になるのかわかりづらい.

・風洞実験と CFD に対する誤解をなくす必要がある. 縮尺模型で 行う風洞実験の精度に対して不信感がある一方, CFD の予測結 果は見栄えが良いこと等もあり過度な期待を持つ場合がある.

・住民から強い要望がある場合, 事後調査の地点の追加や調査結 果の公表に努めるべきである.

問 7 風害に関する住民からの苦情や相談

・高層建築物の建設により, ビル風の影響が賏念される.

・建築物建設後に風環境が悪化した，対策をお願いしたい．

問 8 日本風工学会への要望

・技術・設計提案, 説明資料, 風害対策事例集等の作成.

・上空風データの妥当性の検証.

・風害予測の簡易的なシミュレーション手法の確立.

・予測精度向上のために, 研究活動を継続的に実施してほしい. 
で期待していること，あるいは困っていることの有無に 対する回答割合を図 4 に示す。「ある」との回答が 7 割で あった。その内容の一例を表 4 中に示す。予測ケースや 予測に用いる上空風データの選定等, 風害の予測条件に 対する要望もみられ，行政が風害の予測を行う上でより 実情に即した対応を事業者側に求めていることがわかる。 さらに，防風対策一の過度の期待を懸念寸る意見や事後 調査結果が悪かった場合の適切な対応の要望もあり, 風 害一の対応に苦慮していることも伺える。問 6 の風害 (ビ ル風）の環境影響評価に関して, 住民との対応で改善し たい課題の有無に対する回答割合を図 5 に示寸。約 4 割 が「ある」と回答した。内容の一例を表 4 中に示す。行 政が住民に対して真摰に対応する様子が伺える一方, 風 環境評価指標の表現について, 実際に生じる現象のイメ ージが難しいと感じていることもわかる。

問 7, 問 8 は, 評価制度の有無に係わらず回答してもら う質問である。問 7 の風害（ビル風）に関する住民から の苦情や相談を受けた事例の有無に対する回答割合を図 6 に示す。約 1 割が「ある」と回答している。内容の一例 を表 4 中に示す。建築物建設前に風害を賏念する相談も あるものの, その多くは建築物建設後に実際に風が強く なったことに関する内容であり, 住民が風害と認識し, 行政に対して相談を寄せていることがわかる。問 8 の日 本風工学会への要望への回答の一例を表 4 中に示寸。風 害における課題の解決に向けて, 説明資料, 風害対策事 例集等の作成や風害の予測精度向上への取組等の要望が あった。

\section{5.まとめ}

日本風工学会・都市の風影響評価研究会では, これま でに風環境の予測精度向上に向けて, 2 つの技術的な問題 について取組を行ってきた ${ }^{12)}$ 。1つは風洞実験やCFD で 得られる平均風速を最大瞬間風速に変換する際のガス卜 ファクターの扱い, もう1つは予測に用いる上空風デー タの扱いである。前者は提案式を発表しており, 後者に ついては予測に用いる標準上空風データの公開を予定し ている。今後, これらの取組の成果が, 研究者だけでな く風環境評価に係る実務者に広く周知され, 利用される ことが，今回のアンケートから明らかとなった課題や要 望への答えの一つとなると考える。さらに, アンケート 結果からは環境影響評価において広く利用されている予 測方法（風洞実験，CFD）や評価指標の説明が難しいと の意見や説明資料, 風害対策事例集等の作成の要望も得 られた。風環境評価に係る知見等をわかりや寸い形で,
広く情報発信していくことも本研究会の今後の活動とし て検討したい。

謝辞

アンケート調査にご協力いただいた各自治体の環境影 響評価制度の担当者の方々に，心から謝意を示す。

アンケート調査の項目設定や文案作成に際しては, 日 本風工学会・都市の風影響評価研究会の委員の方々から 貴重なご助言を頂いた。またインターネット調查は, 筆 者らの他, 同研究会の以下の委員により実施された（敬 称略)。ご協力に心から謝意を表す。伊藤 真二（(株）鴻 池組 技術研究所), 片岡 浩人 ((株) 大林組 技術研究 所)，佐々木 澄（清水建設（株）技術研究所），中村 良 平 (大成建設（株）技術センター), 西村 宏昭（京都大 学), 藤井 邦雄 ((株) 風環境少サ一千), 宮下 康一 ((株) 風工学研究所), 山中 徹 (鹿島建設 (株) 技術研究所)

参考文献

1）風工学研究所編著, ビル風の基礎知識, 鹿島出版会, (2005)

2) 吉川優, 自治体の風環境調查に関する指導要綱等, 風環境フォーラム「風環境（ビル風）評価の現状 と課題」資料，pp.120-124，(2005.3)

3) AGCアメニテック株式会社, 地方公共団体の環境 影響評価制度 (風害), http://cae.agac.co.jp/contents/ material/material_25.html, (2018.2)

4) 環境省, 都道府県・市町村における環境影響評 価条例の制定・施行状況等, https://www.env.go.jp/ policy/assess/2-3selfgov/2-3system/index.html， (2018.2)

5) 小林信行, 風環境評価の現状と課題, 日本風工学 会誌, Vol.30, pp.303-306, (2005.7)

6) 東京都環境影響評価条例，(2013.4)

7）東京都環境影響評価技術指針（付解説）,(2014.1)

8) 村上周三, 岩佐義輝, 森川泰成, 居住者の日誌に よる風環境調査と評価尺度に関寸る研究, 日本建 築学会論文報告集，第325 号, pp.74-84，(1983)

9) 東京都総合設計許可要綱実施細目, (2017.3)

10) ビル風対策に係る手引き, (2013.4)

11）川崎市環境影響評価等技術指針 [解説付 ], (2016.1)

12）西村宏昭, 市街地風環境の予測・評価手法の新た な展開に向けて, 日本風工学会誌, Vol.39, pp.149150, (2014.4) 